\title{
Petrography, Temperature Measurement, and Economic Evaluation of Granitoid Pluton of Qohrud-Kashan Using EPMA, XRD, and XRF Analysis
}

\author{
Afshin Ashja Ardalan ${ }^{*}$, Mina Khodadady ${ }^{1}$, Mohammad Hashem Emami², \\ Jamal Sheikh Zakariaie ${ }^{3}$, Mohammad Hosein Razavi ${ }^{4}$, Abdollah Yazdi ${ }^{5}$ \\ ${ }^{1}$ Department of Geology, Faculty of Sciences, Islamic Azad University, North Tehran Branch, Tehran, Iran \\ ${ }^{2}$ Department of Geology, Islamic Azad University, Islamshahr Branch, Islamshahr, Iran \\ ${ }^{3}$ Department of Geology, Faculty of Sciences, Islamic Azad University, Science and Research Branch, Tehran, Iran \\ ${ }^{4}$ Department of Geology, Faculty of Sciences, Kharazmi University, Tehran, Iran \\ ${ }^{5}$ Department of Geology, Islamic Azad University, Kahnooj Branch, Kerman, Iran \\ Email: afshinashjaardalan@yahoo.com
}

Received 1 July 2014; revised 2 August 2014; accepted 25 August 2014

Copyright (C) 2014 by authors and Scientific Research Publishing Inc.

This work is licensed under the Creative Commons Attribution International License (CC BY).

http://creativecommons.org/licenses/by/4.0/

c) (i) Open Access

\section{Abstract}

The area which is being studied is located in northwest of Isfahan, 30 kilometers south of Kashan, and southern section of Qmasar. The longitude of the area of study is $51^{\circ} 19^{\prime} 13^{\prime \prime} \mathrm{E}$ to $51^{\circ} 26^{\prime} 26^{\prime \prime} \mathrm{E}$ and its latitude is $33^{\circ} 34^{\prime} 24^{\prime \prime} \mathrm{N}$ to $33^{\circ} 44^{\prime} 24 " \mathrm{~N}$. Based on microscopic observations, modal analysis, and also based on their location in the Streckeisen [QAPF], both the stones of the Qohrud batholitic mass themselves and its enclaves are more in quartz monzonite ranges. Granitoid also have quartz monzonite enclaves. These enclaves are from both microgranular mafic and Autolith types which indicate the mixing of two magmas. At the center of the pluton, there are indications of existence of main magma reservoir and magma mixing. In terms of mineralogy, the granitoid rocks of the area very much resemble I-type. The zoning of the plagioclases is both the normal kind and variation invert and has andesine general composition. The probed biotite sample contains iron and belongs to a granitic sample from the center of the mass. Also, the ranking graph indicates biotite as the source of recrystallization for the analyzed points. The probed biotite sample of the Qohrud area showed formation temperature of $\mathbf{7 3 0}$ degrees centigrade. According to the $\mathbf{R b}$ and $\mathbf{S r}$ contents, the source of the rocks is at depths of 20 to 30 kilometers from the earth's surface that are depending on the subduction zone. The formation temperature of the specimens of the Qohrud batholithic mass is mostly between 900 to 1000 degrees centigrade. [At] the center of the mass

${ }^{*}$ Corresponding author. 
(around Qahrud), the amount of molybdenum is higher than the economic limit.

Keywords

Kashan, Qohrud, Granitoid, Temperature Measurement, Analysis

\section{Introduction}

Granitoids are the most abundant intrusive rocks in the upper crust; on the other hand, granite rocks are accompanied by mineralization. Therefore, studying them has great importance. The igneous rocks of this region are themselves part of the Urumieh-Dokhtar or Sahand-Bazman volcanic belt. The approximate outcrop of this granitoid mass is 100 square kilometers.

The area which is being studied is located in northwest of Isfahan Province, 30 kilometers south of Kashan, and south of the Qamsar County. This area is adjacent to Qaza’an, Qohrud, and Jovinan parishes (Figure 1).

This area is located at the east side of the 1:100000 geological map of Kashan, in Qohrud mountain range which is illustrated as red granodiorite [1].

\section{Methodology of Research and Processes}

- Arriving at the location and carrying out the primary field operations for determining points and collecting rock samples and documenting ground checkpoints with aid of GPS.

- Sending the samples to the thin section working place for microscopic study of the samples.

- Selecting a number of samples for micro-probe analysis and XRD and XRF.

- Statistical and calculative computer works, final integration of data and conclusion.

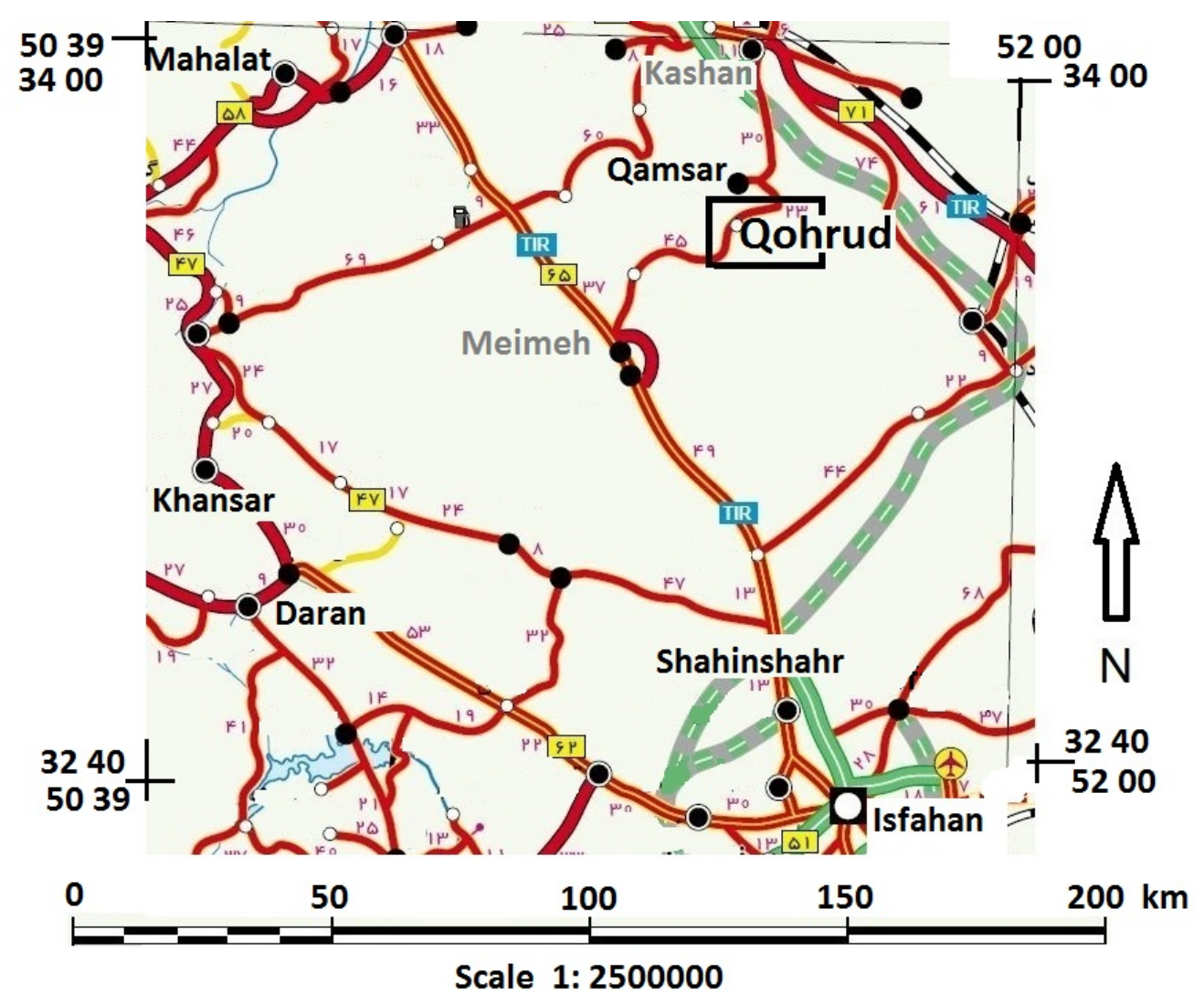

Figure 1. Geographical location of the area with 1:2000000 scale (Internet, 2013). 


\section{Discussion}

\subsection{Field Observations and Studying Geology}

The longitude of the area of study is, $51^{\circ} 19^{\prime} 13^{\prime \prime} \mathrm{E}$ to $51^{\circ} 26^{\prime} 26^{\prime \prime} \mathrm{E}$, and its latitude is $33^{\circ} 34^{\prime} 24^{\prime \prime} \mathrm{N}$ to $33^{\circ} 44^{\prime} 24^{\prime \prime} \mathrm{N}$ (Figure 2). The two dimensional extruded shape of the Qohrud pluton is an anisotropic irregular oval shape and its three dimensional shape resembles a mushroom. Based on the field observations, the closer we get to the center and south of the pluton (around Qohrud) the rock become brighter in color and larger in size. The closer we get to Qohrud, the altitude also increases, yet, on east side of the pluton which is Jouynan Parish the lowest altitude is recorded. In addition, the smallest grain and the darkest rock samples belong to the vicinity of Jouynan at the east of the pluton. As a result of the tectonic forces and hydrothermal solutions, taffoni and onion layer corrosion patterns are evident in the rocks of the area. The samples taken from the Qohrud batholithic mass are of quartz monzonite, granite, granodiorite, and quartzdiorite. Also, number enclaves can be seen.

The enclaves of the area of study are mostly from both microgranular mafic and autolith type and are mostly of quartz monzonite. They are darker and smaller than their host rock and are seen in oval shapes in various sized in granitoids (Figure 3).

\subsection{Microscopic Observations and Naming the Rocks of the Area}

In Figure 4 [2] the designation modal for categorization of the modal of all samples of the Qohrud area is illustrated. Based on Figure 4, the majority of the samples that have been collected from Qohrud area occupy the quartz monzonite zone in the graph.

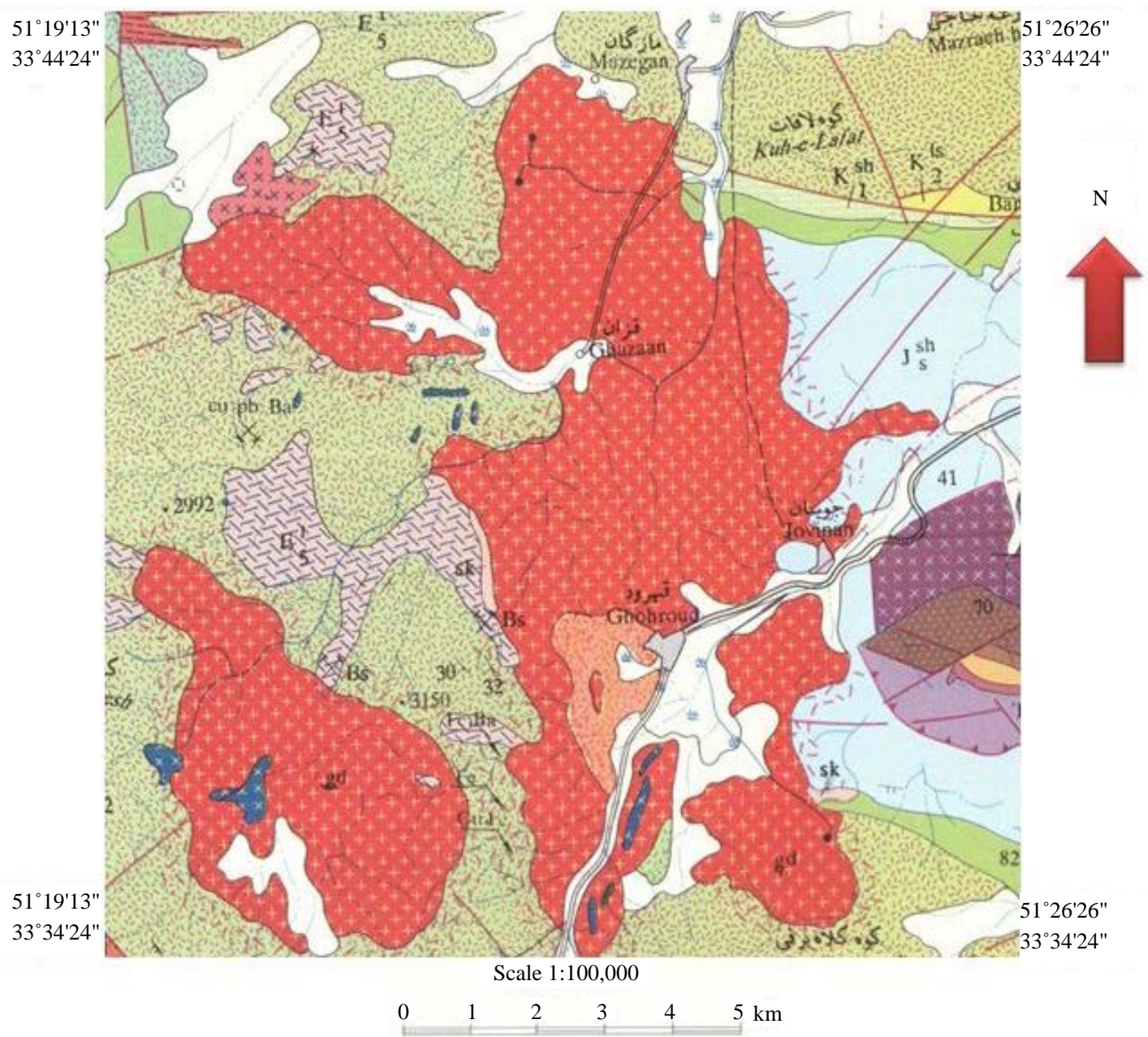

(a) 


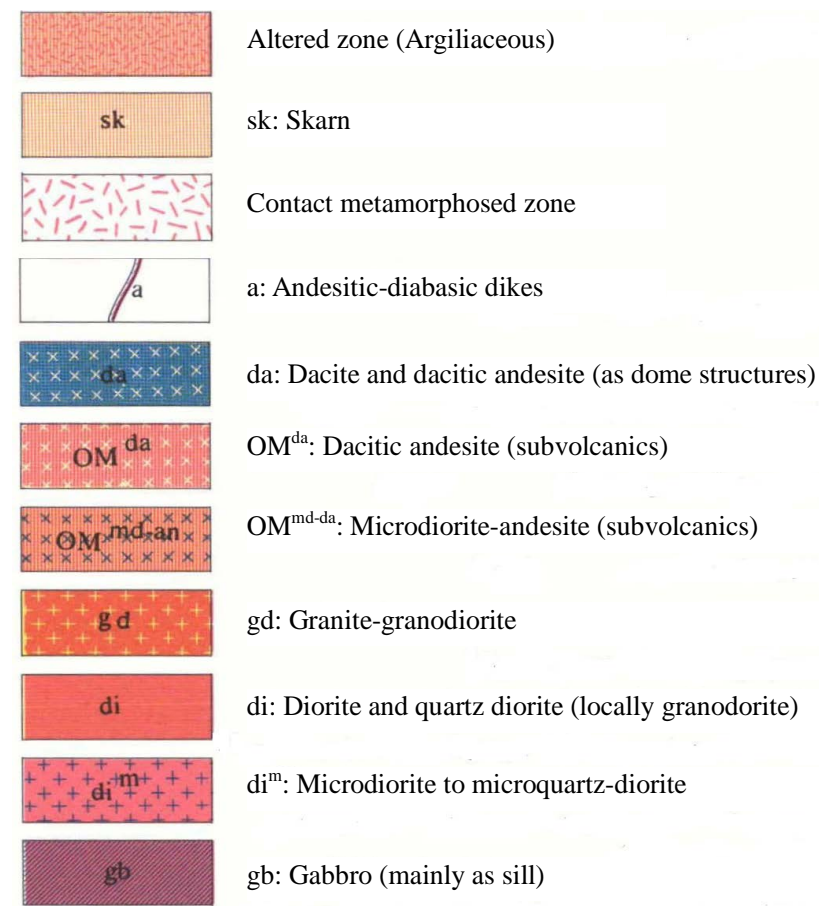

(b)

Figure 2. (a) Geological map of the area with 1:100000 scale and more magnification (Zahedi, 1991) [1]. (b) Legend of Geological map of the area with 1:100000 scale (Zahedi, 1991) [1].

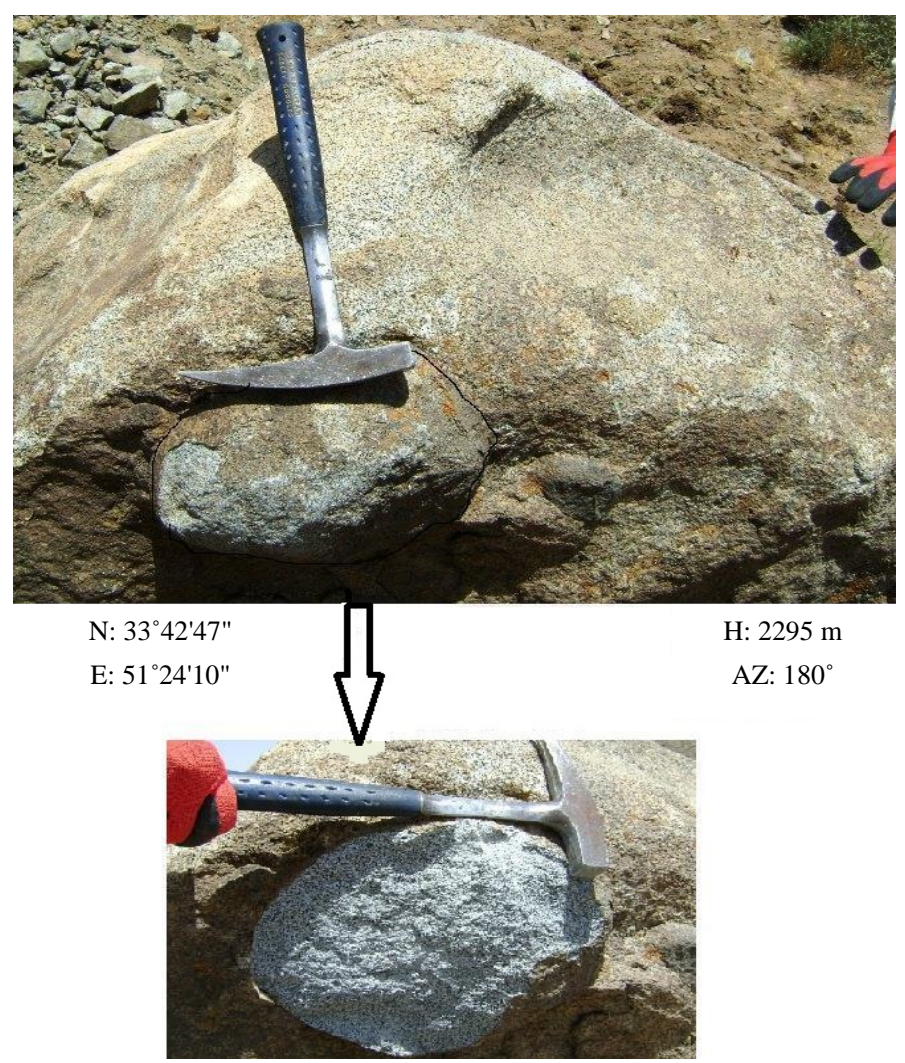

Figure 3. Enclave sample from granitoides of the area pre and post of breaking. 


\section{QAPF diagram - Si oversaturated}

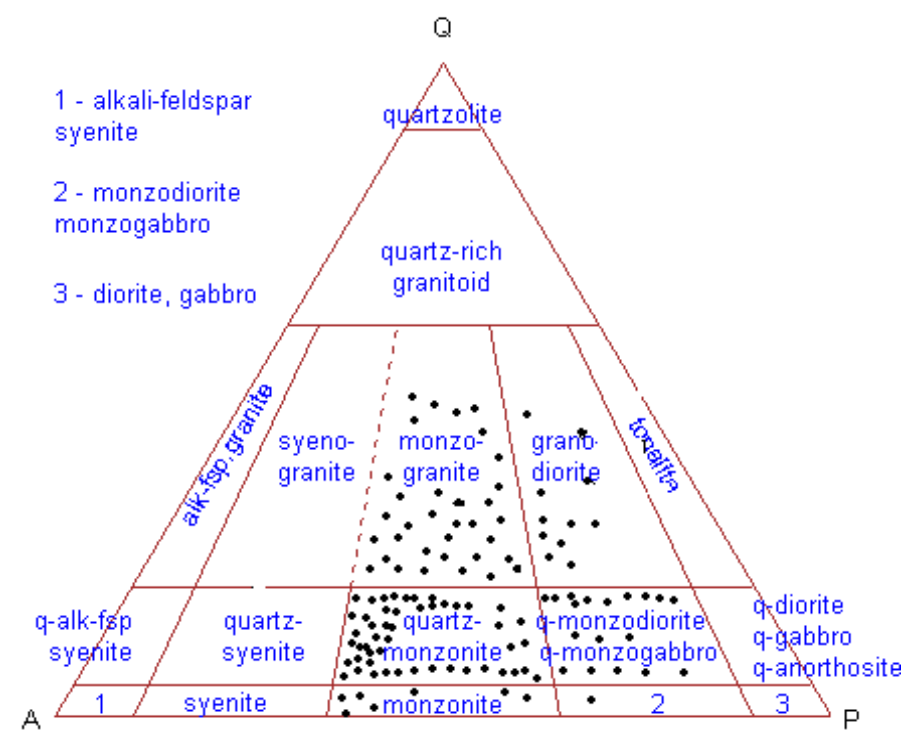

Figure 4. Modal naming of rocks of the area based on QAP diagram (Streckisen, 1973) [2].

\subsection{Quartz Monzonite Petrography of the Area}

The most abundant rocks in the region are quartz monzonites. Based on the microscopic observations of quartz monzonites, the main minerals include quartz; biotites, orthose, Plagioclase and hornblende type amphibole, and accessory minerals include zircon, apatite, sphene, and opaque minerals. Alteration minerals include kaolinite, chlorite and sericite. These rocks usually have medium to large granular texture; in a way that these grains can be as large as 4 millimeters. In one of the microscopic thin sections, the size of the grains reached approximately 3 to 10 millimeters. In some, inter-granular textures are observed. The color coefficient is mesocratic (semi light). Quartz monzonite dispersal is mostly observed at the east of the mass around the Jouynan Parish.

Descriptions of the minerals include:

- Plagioclase: Intermediate with zoning and generally includes andesine and oligoclase (based on electron microprobe method). Of course, some plagioclases are without zoning and highly automorphic. Plagioclase constitutes 25 to 50 percent of the sample volume. Pericline and polysynthetic macles are evident in them. In one of the samples, their size reached 8 millimeters while in average the background is grains that are 2 millimeters in size. Some plagioclases show interfered growth and circular zoning. Generally, they are kaolinitized to a high degree and slightly sericitized. Some of them are highly automorphic and their growth seems to be higher and without zoning, so that it is possible that their generation might be different from the zoned plagioclases.

- Quartz: They are generally seen shapeless and constitute 5 to 20 percent of the sample volume. Their size varies from 0.5 to 1 millimeter.

- Amphibole: They are usually the hornblende type, seen in green and brown colors in thin-sections. Hornblende grains are sometimes sub-automorphic to automorphic and have perfect or irregular hexagonal shapes. Their volume percentage in cross-sections is 3 to 30 percent. Some of them opacitized and chloritized. Some amphibole grains have carlsbad macle (Figure 5).

- Orthose: Its volume if 25 to 50 percent. Some of them are kaolinitized and sericitized.

- Biotite: They are present in rocks as plates and their volume reaches 5 to 10 percent. Biotite is commonly shows to be of the brown and strong multicolor variety. Some of them are opacitized and chloritized.

- Accessory and secondary minerals: Zircon is seen in oval, prismatic, and haloed shapes in biotites. Apatite is colorless and in form of bars or oblong shaped. Sphene is brown in color, and is seen triangular with dagger 
like edges, identified with its high prominence. Opaque minerals have lesser presence. Opaque is present in both secondary (small grain, resulted from opacitization of amphibole) and primary (relatively larger grains and sub-automorphic to automorphic).

Figure 5 illustrates quartz monzonite along with specifications of the minerals and textures. Images are shot in both XPL and PPL modes. Magnification and the length of the field of view are written on the image itself.

\subsection{Indications of Magma Mixing in Qohrud Area and Proving [The Existence of] Various Types of Magma in the Region}

\section{A) Presence of automorphic minerals only in south of the mass:}

In granitoid rocks of the Qohrud batholithic mass, automorphic and healthy plagioclase minerals with polysynthetic macle are present (Figure 6). Also, biotite minerals in the rocks of the area are generally healthy and have shaped zircon and haloed inclusions. Presence of healthy automorphic to sub-automorphic biotites with brown polychroism which have incorporations of low expanse automorphic zircon crystals with polychromic halos is an indication of crystallization from melt anatexis [3].

As it was previously mentioned, at the center and at the south of the mass, rocks become brighter and more acidic and are generally granite. With regard to this matter, and the presence of automorphic and healthy minerals in south of the mass, the possibility of integration of acidic and intermediate magma in the middle sections of the mass can be taken into consideration.

Presence of healthy and large hornblende in the majority of the samples indicates that during some intervals of its evolution, the magma has been rich with water. Because, in case of stability of hornblende in magma, the water content of magma must be over 4\% [4]. In rocks at the center of the mass—around Qohrud Parish-biotite minerals have stress bends which can only be seen in this part of the area. Therefore, there is more stress in Qohrud area. Possibly, the center of the mass is the location of ascent and impact of two magmas, because, with regard to what has been previously mentioned, mafic microgranular enclaves which have irregular shapes and toothed contact surfaces are usually formed in places where magma mixing process has been active.
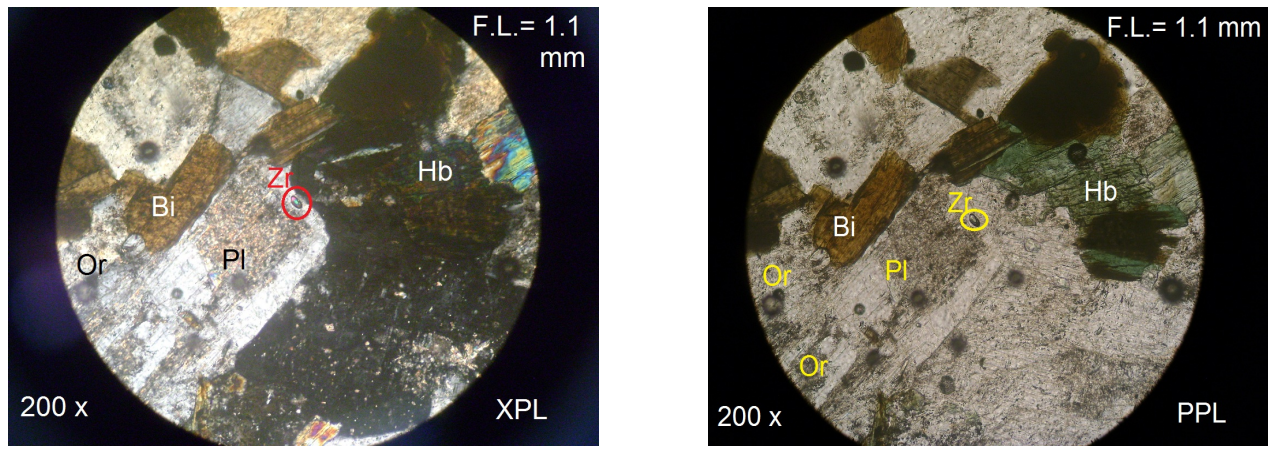

Figure 5. Zircon in centre and kaolinitized Orthose to and sericitized Plagioclase and hornblend $(200 \times)$.
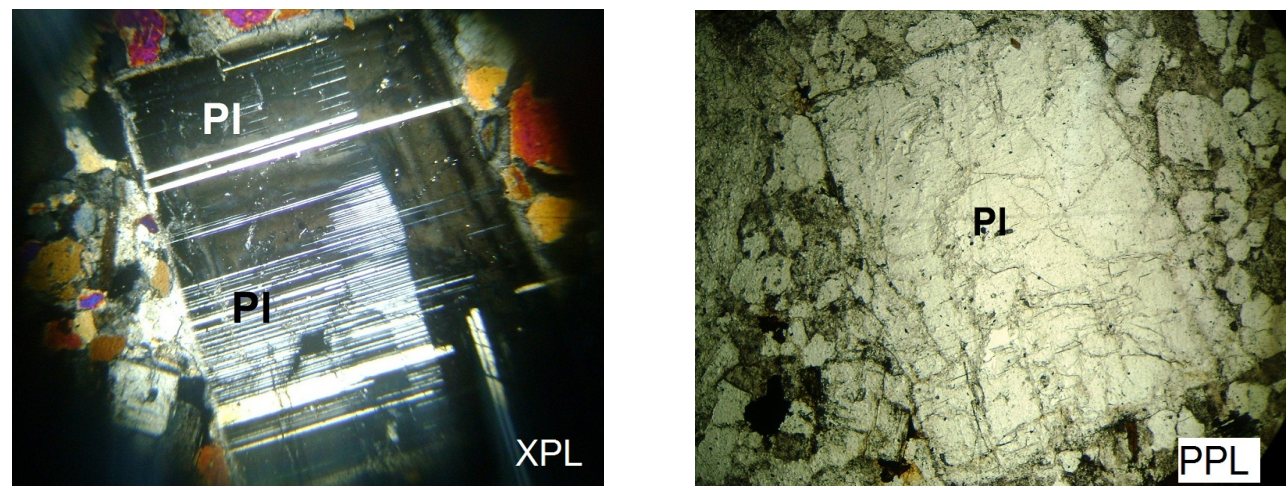

Figure 6. Plagioclase mineral is highly automorph from granitoids of south of Qohrud (40×). 
Therefore, the center and the south of the mass show indications of the presence of more acidic magma and anatexis melting, and at the center of the mass, evidence of magma mixing and existence of a main magma reservoir can be seen.

\section{B) Existence of mafic microgranular enclaves with irregular shape:}

This type of enclaves which are seen in the rocks of the area, are signs of magma mixing [5]. Mafic microgranular with irregular shape and toothed contact surfaces are usually seen in places where magma mixing process has been active [6]. Some articles point to special microstructures in enclaves which are seen in interference zones. These structures include tooth like margins, elongated, lens like, plate like, disk like and circular enclaves and magma infusion with felsic and mafic combination in the area can be a possibility [7]. In the area of study, these shapes can be seen as well.

C) Presence of reactive margins at the border of the enclaves with their host rock and needle apatites:

In microscopic level, some rocks in the northern part of the pluton have reactive margins (Figure 7) which illustrates the border of the host rock with enclave. In these sections, quartz minerals have bar-like and needle shaped apatite minerals. With regard to the fact that possibly in terms of occurrence, the (primary) fluid and solid incorporations precede their host minerals [8], citing [9]; therefore, the occurrence of apatites is prior to formation of quartz. Even though apatite can be seen in other sections of the enclaves, it is not present in the host rock. This indicates the partial absorption of the enclave in magma. Also, [10] believes that the presence of needle like apatite crystals is an indirect sign of magma mixing during which molten basic has been rapidly frozen by acidic magma (Figure 7).

\section{D) Presence of unbalanced textures such as invert zoning and fluctuation in plagioclases:}

Unbalanced textures such as plagioclase zoning can be a sign of magma mixing. Zoning in plagioclases of the area is of the normal type, both invert and fluctuating (Table 4).

\section{E) Two generations of mineral in one Thin-section:}

Also, the great difference between the sizes of the grains in one cross-section and evidence of presence of two generations of mineral suggests different conditions for crystal growth in the magma (Figure 8).

F) Presence of phenocryst plagioclases in microgranular enclaves:
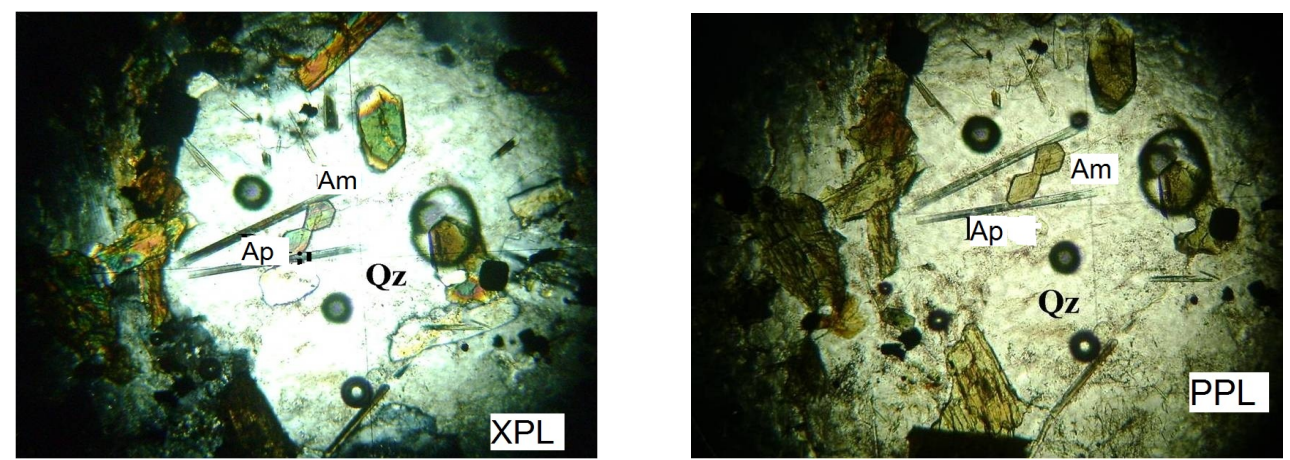

Figure 7. Apatite in form of needle in reactive margin at the border of the enclaves with their host $\operatorname{rock}(100 \times)$.
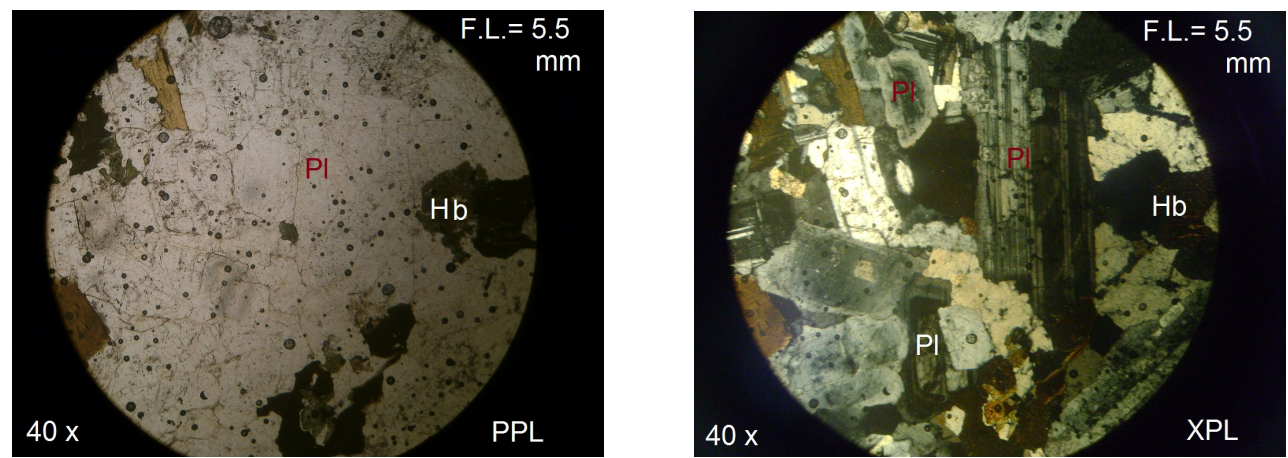

Figure 8. Presence of two generation of Plagioclase $(40 \times)$. 
In Figure 9 of quartz monzonite enclave, there is a large grain of plagioclase at the center of the image which in terms of size is completely different from the background.

\section{G) Presence of sieve texture regarding plagioclases:}

Some researchers such as [11] believe that even though the process for the formation of sieve texture in plagioclases by magma integration is inevitable (Figure 10), yet, the more observation of this texture cannot be considered as an irrefutable evidence of magma integration; because, the formation of this texture can be due to sudden drops in pressure (accompanied by slight drop in temperature or without changes in temperature).

$H$ ) Presence of secondary quartz veinlet in the microscopic thin section from the northern area:

In Figure 11, a secondary veinlet which is mainly consisted of quartz grains has penetrated in the granodiorite of the north part of the area.

\section{I) Elongated crystals in enclaves:}

Elongated crystals and medium grain texture in enclave number 29 indicate the magma current.

\section{J) Overgrowth of minerals in from of plagioclase and amphibole incorporation within the quartz:}

In Figure 12, quartz mineral has enveloped the plagioclase and amphibole. The overgrowth process indicates a sudden change in composition or magma crystallization conditions [12].
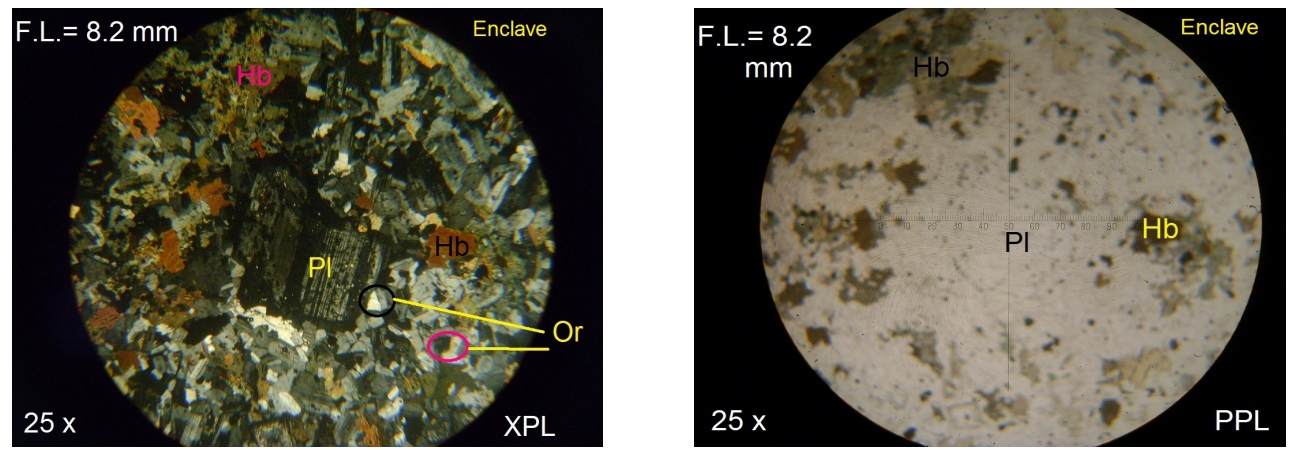

Figure 9. Presence of phenocryst Plagioclase in microgranular enclave (25×).
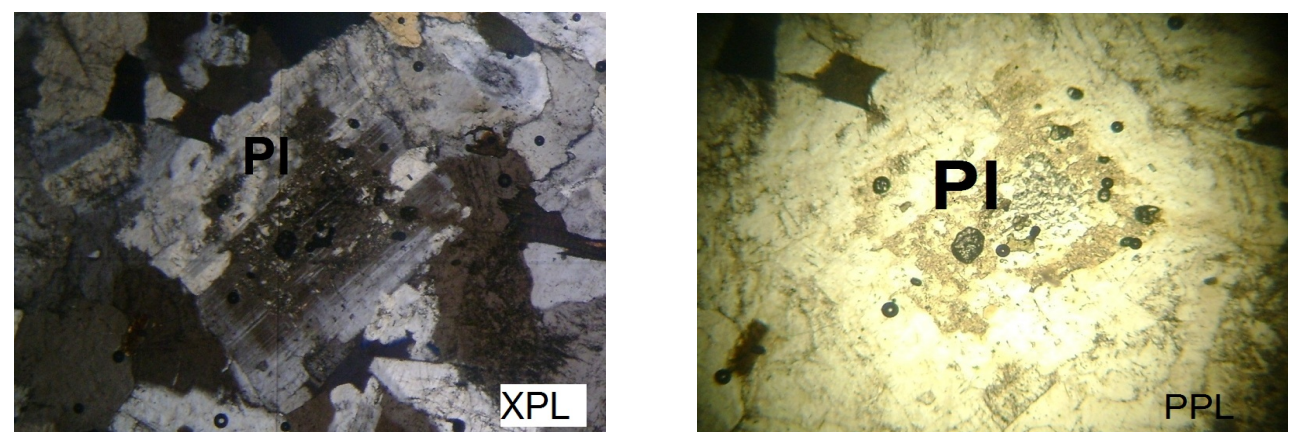

Figure 10. Sieve texture and zoning in Plagioclase $(40 \times)$.
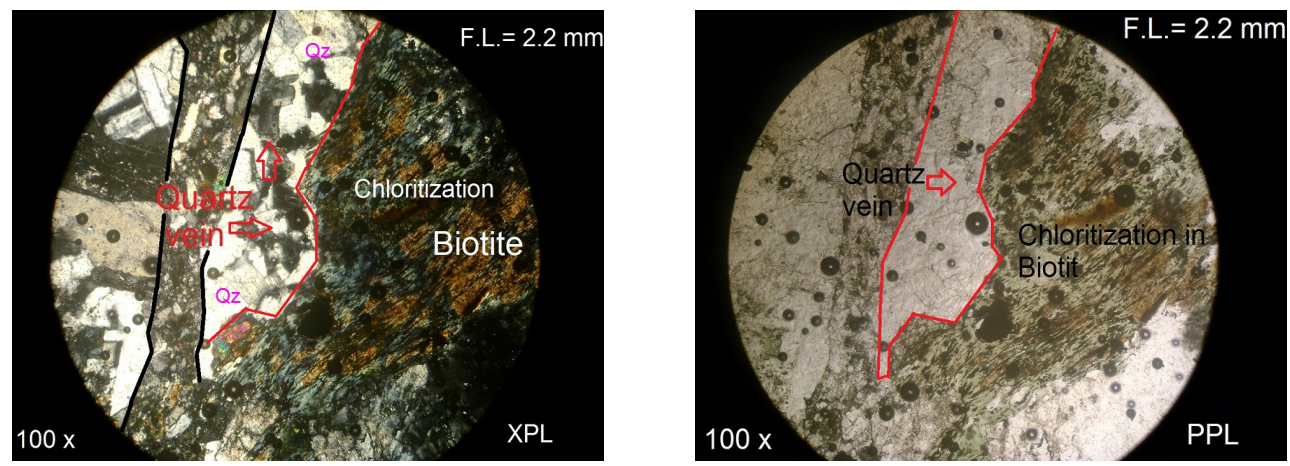

Figure 11. Quartz veinlet and chloritization in Biotite (100×). 


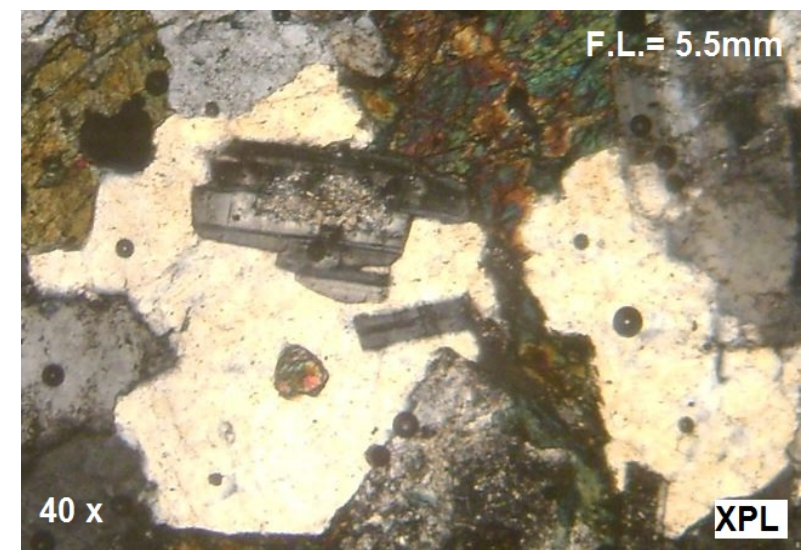

Figure 12. Plagioclase and amphibole within the quartz (40×).

\section{K) Presence of quartz gabbro in west Qohrud:}

In his MA thesis, [13] points to the presence of quartz gabbro in west Qohrud which is located in Azhineh area of Qohrud and indicates the presence of basic magma in this part of the area. Pyroxene diorites also have been reported. However, in this thesis gabbro was not observed.

L) The source of Varandan Qaza'aan iron deposit and immiscibility:

Based on field observations, petrography and mineralogy, [14] conclude that the source of Varandan Qaza'aan iron deposit is magmatic and primary which has been formed magnetically along with silicates and by magmatic segregation of the fluid immiscibility type.

M) Presence of microperthite in mineralogy studies:

In section (5-3), in sample 12 of mineralogy studies a table, microperthite has been detected which can be a sign of unbalanced micro texture and magma integration.

\subsection{XRD Mineralogy Analysis}

12 of the Qohrud area rock samples were analyzed using the XRD mineralogy analysis machine at the Northern Tehran Branch of the Islamic Azad University and the results for sample are described in Table 1.

With regard to the mentioned table, the minerals resulted from the XRD mineralogy analysis approximately matched the results from the microscopic and modal observations. The compassion between these two methods reveals that minerals such as uraninite and torianite which were not observed under the microscope were clearly distinguished using the XRD method. These results reveal precise and real mineralogy composition of the samples.

\subsection{Designation Graphs of the Rocks of the Area Using the Chemical Analysis Data}

To designate different rock groups of the area using the chemical analysis data and norms of different diagram are used. One of such graphs is [15] in Figure 13.

In this graph, samples are mostly positioned in adamite (quartz monzonite) section Figure 20, Table 2.

\subsection{Quantitative Analysis-Spot Microprobe Electron of the Plagioclase and Biotite Minerals}

Using the electron microprobe analysis method for precise determination of different types of minerals, especially minerals with series solid solution can aid us in accurate designation on the type of plagioclases and biotites present in plutonic rocks of the area. Also, the type of zoning and the anorthite percentage in plagioclase mineral can be determined. Biotites will determine the source as well. For this, 10 samples from the Qohrud area were analyzed using the nuclear spot microprobe machine at the Kansaran (Mineralized) Binaloud Tehran Company under special conditions; each thin section was probed in five spots and the mineral results from their chemical formula were described in the following tables. The shape of the anomalies, spots designated in thin sections, and complete results are enclosed in the attachment section. From each plagioclase mineral 5 points 
Table 1. XRD analysis and names of minerals and chemical formula in 12 sample.

\begin{tabular}{|c|c|c|}
\hline M12 & & Sample number \\
\hline Ref. Code & Compound name & Chemical formula \\
\hline 01-086-1560 & Quartz low & $\mathrm{SiO}_{2}$ \\
\hline 01-085-1415 & Anorthite (Na-exchanged) & $\left(\mathrm{Na}_{0.45} \mathrm{Ca}_{0.55}\right)\left(\mathrm{Al}_{1.55} \mathrm{Si}_{2.45} \mathrm{O}_{8}\right)$ \\
\hline 01-083-1895 & Microperthite & $\mathrm{K}_{0.96} \mathrm{Na}_{0.04} \mathrm{Al} \mathrm{Si}_{3} \mathrm{O}_{8}$ \\
\hline 01-076-0885 & Biotite 2M1 & $\mathrm{KMg}_{2} \mathrm{Al}_{2} \mathrm{Si}_{3} \mathrm{O}_{11}(\mathrm{OH})$ \\
\hline 00-024-0506 & Clinochlore-1\ITM\#I\#I\#b\RG & $\left(\mathrm{Mg}_{5} \mathrm{Al}\right)(\mathrm{Si}, \mathrm{Al})_{4} \mathrm{O}_{10}(\mathrm{OH})_{8}$ \\
\hline 00-012-0636 & Wyartite-17A & $\mathrm{Ca}_{3} \mathrm{U}\left(\mathrm{UO}_{2}\right)_{6}\left(\mathrm{CO}_{3}\right)_{2}(\mathrm{OH})_{18} \cdot 3 \mathrm{H}_{2} \mathrm{O}$ \\
\hline 01-086-2342 & Calcite & $\mathrm{Ca}\left(\mathrm{CO}_{3}\right)$ \\
\hline 00-039-0346 & Orthoserpierite & $\mathrm{Ca} \mathrm{Cu}_{4}\left(\mathrm{SO}_{4}\right)_{2}(\mathrm{OH})_{6} ! 3 \mathrm{H}_{2} \mathrm{O}$ \\
\hline 01-085-0395 & Titanite & $\mathrm{Ca} \mathrm{Ti} \mathrm{Si} \mathrm{O}_{5}$ \\
\hline 01-077-2350 & Lemoynite & $\mathrm{Na}_{2} \mathrm{Ca} \mathrm{Zr}_{2} \mathrm{Si}_{10} \mathrm{O}_{26}\left(\mathrm{H}_{2} \mathrm{O}\right)$ \\
\hline 01-086-0417 & Cheralite (Ce) & $\left(\mathrm{Ce}_{0.4} \mathrm{Ca}_{0.3} \mathrm{Th}_{0.3}\right)\left(\mathrm{PO}_{4}\right)$ \\
\hline 01-075-0420 & Uraninite \$-alpha & $\mathrm{UO}_{2}$ \\
\hline
\end{tabular}

Debon and Le Fort P - Q

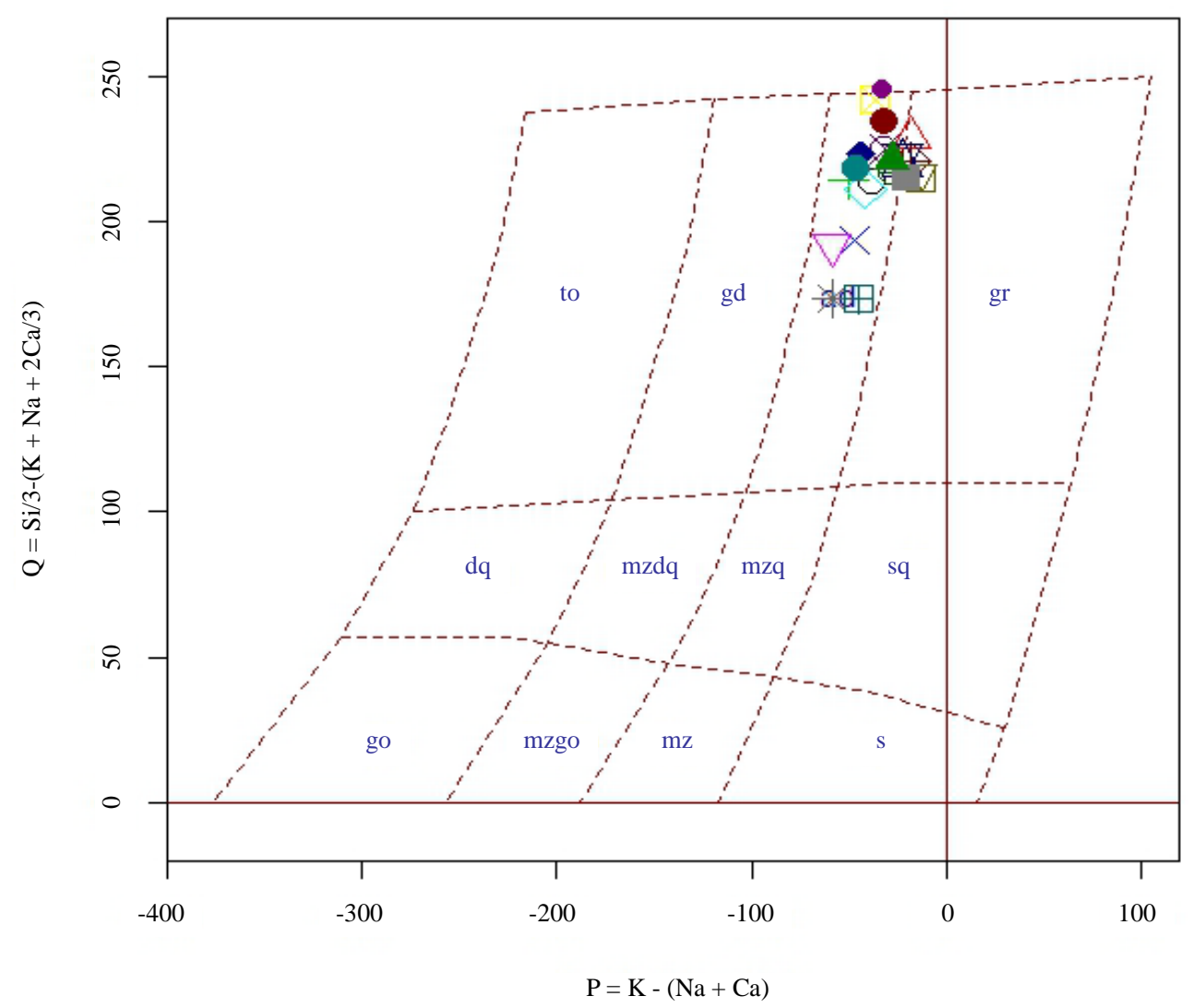

Figure 13. P-Q plot for naming of the granitoids of the area in use of XRF analysis (Debon and Le Fort, 1983), [15]. [Ad: Adamelite (quartzmonzonite)]. 
Table 2. XRF analysis and sample numbers from Qohrud area (department of geology of Iran-Tehran, 2012), [27].

\begin{tabular}{|c|c|c|c|c|c|c|c|}
\hline Sample number & $\mathrm{SiO}_{2}$ & $\mathbf{A l}_{2} \mathbf{O}_{3}$ & MgO & $\mathbf{K}_{2} \mathbf{O}$ & $\mathrm{TiO}_{2}$ & MnO & $\mathrm{CaO}$ \\
\hline M1 & 60.7 & 17.2 & 2.4 & 2 & 0.7 & 0.1 & 5.9 \\
\hline M12 & 63.7 & 16 & 2.1 & 2.5 & 0.6 & 0.2 & 5 \\
\hline M13 & 59.9 & 17.6 & 2.7 & 1.6 & 0.7 & 0.1 & 6.3 \\
\hline M16 & 57.9 & 18 & 2.7 & 1.9 & 0.8 & 0.2 & 6.6 \\
\hline M23 & 63.2 & 16.5 & 2.2 & 2.3 & 0.7 & 0.2 & 5 \\
\hline M29 & 58.9 & 17.4 & 2.6 & 1.8 & 0.8 & 0.2 & 5.8 \\
\hline M35 & 68.5 & 15.5 & 1.4 & 2.4 & 0.4 & 0.1 & 3.9 \\
\hline M46 & 55.6 & 17.9 & 3.5 & 1.8 & 0.7 & 0.3 & 7.2 \\
\hline M52 & 66.8 & 16.1 & 1.7 & 3.1 & 0.5 & 0.01 & 3.9 \\
\hline M57 & 65.5 & 16.4 & 2 & 2.8 & 0.5 & 0.01 & 4.2 \\
\hline M65 & 66.1 & 16 & 2.1 & 2.9 & 0.5 & 0.01 & 4.1 \\
\hline M71 & 56.9 & 18 & 3.3 & 2.3 & 0.8 & 0.2 & 6.2 \\
\hline M77 & 63.9 & 16.3 & 2.2 & 2.3 & 0.7 & 0.1 & 4.9 \\
\hline M84 & 58.6 & 13.4 & 4 & 2.3 & 1.1 & 0.2 & 5.3 \\
\hline M90 & 65.4 & 16 & 2.1 & 3 & 0.6 & 0.1 & 4.3 \\
\hline M97 & 65.6 & 15.8 & 1.9 & 2.3 & 0.6 & 0.1 & 4.6 \\
\hline M99 & 66.3 & 15.9 & 1.9 & 2.8 & 0.6 & 0.01 & 4.1 \\
\hline M103 & 62.7 & 16.9 & 2.1 & 1.9 & 0.7 & 0.1 & 5.4 \\
\hline M119 & 59 & 18.1 & 3.2 & 1.5 & 0.6 & 0.1 & 6.8 \\
\hline M33 & 70.9 & 15.3 & 1 & 2.7 & 0.3 & 0.01 & 3.2 \\
\hline Sample number & $\mathbf{P}_{2} \mathbf{O}_{5}$ & BaO & $\mathrm{SO}_{3}$ & LOI & $\mathrm{Fe}_{2} \mathrm{O}_{3} \mathrm{t}$ & $\mathrm{FeO}$ & FeOt \\
\hline M1 & 0.2 & 0.01 & 0.01 & 1.16 & 7 & 4.8 & 5.3 \\
\hline M12 & 0.2 & 0.01 & 0.01 & 1.68 & 5.9 & 3.8 & 4.2 \\
\hline M13 & 0.2 & 0.01 & 0.01 & 0.83 & 7.2 & 5 & 5.5 \\
\hline M16 & 0.3 & 0.01 & 0.01 & 0.72 & 8 & 5.7 & 6.3 \\
\hline M23 & 0.2 & 0.01 & 0.01 & 0.86 & 5.9 & 3.7 & 4.11 \\
\hline M29 & 0.2 & 0.01 & 0.01 & 1.01 & 8.1 & 5.8 & 6.4 \\
\hline M35 & 0.2 & 0.01 & 0.01 & 0.62 & 4.1 & 2.2 & 2.4 \\
\hline M46 & 0.4 & 0.01 & 0.01 & 0.87 & 8.6 & 6.4 & 7.11 \\
\hline M52 & 0.2 & 0.01 & 0.01 & 0.79 & 3.9 & 1.9 & 2.11 \\
\hline M57 & 0.3 & 0.01 & 0.01 & 1.05 & 4.3 & 2.3 & 2.5 \\
\hline M65 & 0.2 & 0.01 & 0.01 & 0.89 & 4.3 & 2.3 & 2.5 \\
\hline M71 & 0.3 & 0.2 & 0.1 & 1.3 & 7.4 & 5.1 & 5.6 \\
\hline M77 & 0.2 & 0.01 & 0.01 & 0.77 & 5.8 & 3.6 & 4 \\
\hline M84 & 0.4 & 0.01 & 0.01 & 0.93 & 11.5 & 8.9 & 9.8 \\
\hline M90 & 0.2 & 0.01 & 0.01 & 0.61 & 4.8 & 2.7 & 3 \\
\hline M97 & 0.2 & 0.01 & 0.01 & 0.68 & 5.3 & 3.2 & 3.5 \\
\hline M99 & 0.2 & 0.01 & 0.01 & 0.72 & 4.4 & 2.3 & 2.5 \\
\hline M103 & 0.3 & 0.01 & 0.01 & 0.63 & 6.4 & 4.2 & 4.6 \\
\hline M119 & 0.3 & 0.01 & 0.01 & 1.25 & 6.6 & 4.5 & 5 \\
\hline M33 & 0.1 & 0.01 & 0.01 & 0.58 & 2.9 & 1.1 & 1.2 \\
\hline
\end{tabular}


were microprobe analyzed, each of the spots are located on different places on the mineral, such as the core and the margin (Tables 3-5).

A) Determining the type of zoning, designation, and the source of plagioclases using the electron microprobe analysis results

With regard to the analysis results, weight percentage, and elements' nuclear percentage, anorthite mineral percentage is calculated. In respect to the percentage of anorthite at the core and the margin of the plagioclase and its alterations, they type of zooming is determined.

Also, the designation of the plagioclase is concluded. The anorthite percentage of the plagioclase is calculated based on the following formula from analysis data.

An\% $=($ atomic\% Ca/atomic\% $\mathrm{Ca}+\mathrm{Na}) * 100$.

The zoning of the majority of plagioclases is of the normal, invert, and also oscillating type (Table 4) and have general andesine composition; in a way that the core of the mineral has more calcium than its margins; so, this is a sign of magma deduction. In condition were magma freezes slowly plagioclase feldspars that will form later will be homogenous with plagioclase feldspars that are formed in the beginning, the homogenization of these two types of plagioclase through ion distribution occurs in solid state. In rapid freeze, subsequent (more acidic) plagioclases are formed around the initial plagioclases (basic) in concentric layers and as the result, plagioclases with zoned structure are produced [16]. So, magma has cooled rapidly.

Table 3. EPMA analysis and mean of mass percent of elments in 65 Biotitesample of Qohrud.

\begin{tabular}{|c|c|c|c|c|c|c|c|c|c|c|}
\hline Element & $\mathrm{Na}$ & Mg & Al & Si & $\mathbf{S}$ & $\mathbf{K}$ & $\mathrm{Cr}$ & Ga & $\mathbf{T i}$ & Mn \\
\hline wt $\%$ & 0.24 & 7.8 & 6.2 & 19 & 0.05 & 6.7 & 1 & 0.12 & 2.6 & 0.09 \\
\hline Element & $\mathrm{Fe}$ & $\mathrm{Zr}$ & $\mathrm{O}$ & $\mathrm{H}_{2} \mathrm{O}$ & $\mathrm{TiO}_{2}$ & $\mathrm{MgO}$ & $\mathrm{Fe}_{2} \mathrm{O}_{3}$ & $\mathrm{MnO}_{2}$ & $\mathrm{FeO}+\mathrm{MnO}$ & $\mathrm{TiO}_{2}+10$ \\
\hline wt $\%$ & 9 & 1 & 39.2 & 8.7 & 5.2 & 10.1 & 13 & 0.17 & 11.8 & 15.2 \\
\hline Element & $\mathrm{Al}+\mathrm{Fe}+\mathrm{Ti}$ & $\mathrm{Fe}+\mathrm{Mn}$ & $\mathrm{Mg} / \mathrm{Mg}+\mathrm{Fe}$ & $\mathrm{SiO}_{2}$ & & & & & & \\
\hline wt\% & 73.6 & 9.09 & 0.5 & 38 & & & & & & \\
\hline
\end{tabular}

Table 4. EPMA analysis and mean of mass percent of elements in 65 Plagioclase sample of Qohrud.

\begin{tabular}{|c|c|c|c|c|c|c|}
\hline $\mathrm{Na}$ & Mg & Al & Si & $\mathrm{S}$ & $\mathbf{K}$ & $\mathrm{Cr}$ \\
\hline 4 & 0.01 & 12 & 30 & 0.14 & 0.3 & 0.3 \\
\hline $\mathrm{Ca}$ & $\mathrm{Ti}$ & $\mathrm{Mn}$ & $\mathrm{Fe}$ & $\mathrm{Zr}$ & $\mathrm{O}$ & \\
\hline 4 & 00 & 0 & 0.16 & 0 & 48.5 & \\
\hline
\end{tabular}

Table 5. EPMA analysis and mass percent of An in Plagioclases spot of samples of Qohrud for finding zoning type.

\begin{tabular}{|c|c|c|c|c|c|c|c|}
\hline Sample number & $\begin{array}{c}\text { Spot } 1 \\
\text { An \% }\end{array}$ & $\begin{array}{c}\text { Spot } 2 \\
\text { An \% }\end{array}$ & $\begin{array}{l}\text { Spot } 3 \\
\text { An } \%\end{array}$ & $\begin{array}{c}\text { Spot } 4 \\
\text { An \% }\end{array}$ & $\begin{array}{l}\text { Spot } 5 \\
\text { An \% }\end{array}$ & Plagioclase name & Zoning type \\
\hline 13 & 39 & 44 & 73 core & 58 & 36 margin & Andesine & Normal \\
\hline 16 & 51 & 50 & 33 & $\begin{array}{c}45 \\
\text { core }\end{array}$ & 31 margin & Andesine & Oscillating zoning. \\
\hline 23 & 12 margin & 44 & 39 core & 41 & 40 & Andesine & Oscillating zoning. \\
\hline 33 & 48 margin & 44 core & 45 & 48 margin & 43.5 & Andesine & Inverted \\
\hline 46 & 45 & 50 core & 37 & 41 & 36.6 margin & Andesine & Oscillating zoning. \\
\hline 52 & 42 & 43 core & 41 & 28.5 & 20.7 margin & Andesine & Normal \\
\hline 84 & 36 & 56 & 46 core & 49 & 35 margin & Andesine & Oscillating zoning. \\
\hline 90 & 42 & 46.6 core & 24 & 44 & 47 margin & Andesine & Inverted \\
\hline 103 & 42 & 28 & 8 margin & 64 & 42 & Andesine & Normal \\
\hline
\end{tabular}


The Ab-An-Or designation graph for the probed feldspar minerals is described in Figure 14.

Based on this graph, in samples of the Qohrud area plagioclases are of andesine type. At the core of the plagioclases, the percentage of anorthite is greater than that of the margins which indicates normal oscillating zoning. But som of them are inverted zoning.

\section{B) Determining the type and source of biotites using the electron microprobe analysis results}

Electron microprobe analysis for determining the type and source of biotites is done using the graphs of [17] [18]. Figure 15 and Figure 16 are related to these.

Based on these graphs, the probed biotite sample is of iron biotite which belongs to a granite rock sample from the center of the mass. Also, the ranking graph reveals the recrystallized source for the analyzed spots of the biotite. So, the biotite has been rebalanced.

\section{C) Temperature measurement of minerals using the electron microprobe analysis}

Using the electron microprobe analysis results for the biotite and plagioclase minerals, temperature can be measured; Figure 17 is for biotite temperature measurement plot.

[19] suggest that Ti and Xmg present at the formula unit of the biotites is used as temperature measurement based on the following equation:

$$
\begin{aligned}
& \mathrm{T}=\left\{\left[\ln (\mathrm{Ti})-a-c(\mathrm{Xmg})^{3}\right] / b\right\}^{0.333} \\
& \mathrm{~T}=\text { Temperature in centigrade } \\
& \mathrm{XMg}=\mathrm{Mg} / \mathrm{Mg}+\mathrm{Fe}
\end{aligned}
$$

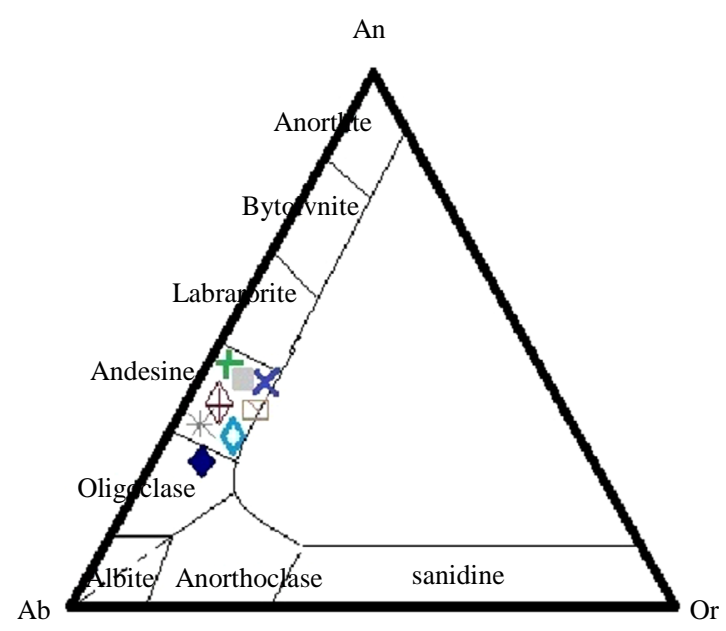

(a)
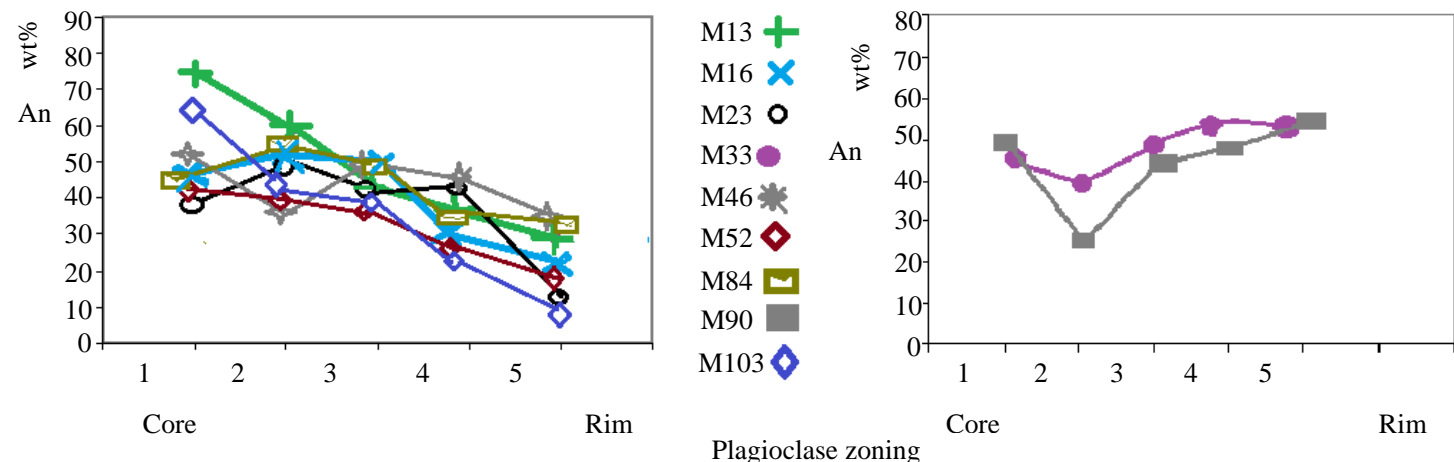

(b)

Figure 14. (a) Ab-An-Or plot for naming plagioclase using EPMA (Deer, 1992) [29]. (b) EPMA analysis and mass percent of An in Plagioclases spot of samples of Qohrud for finding zoning type (Deer, 1992) [29]. 

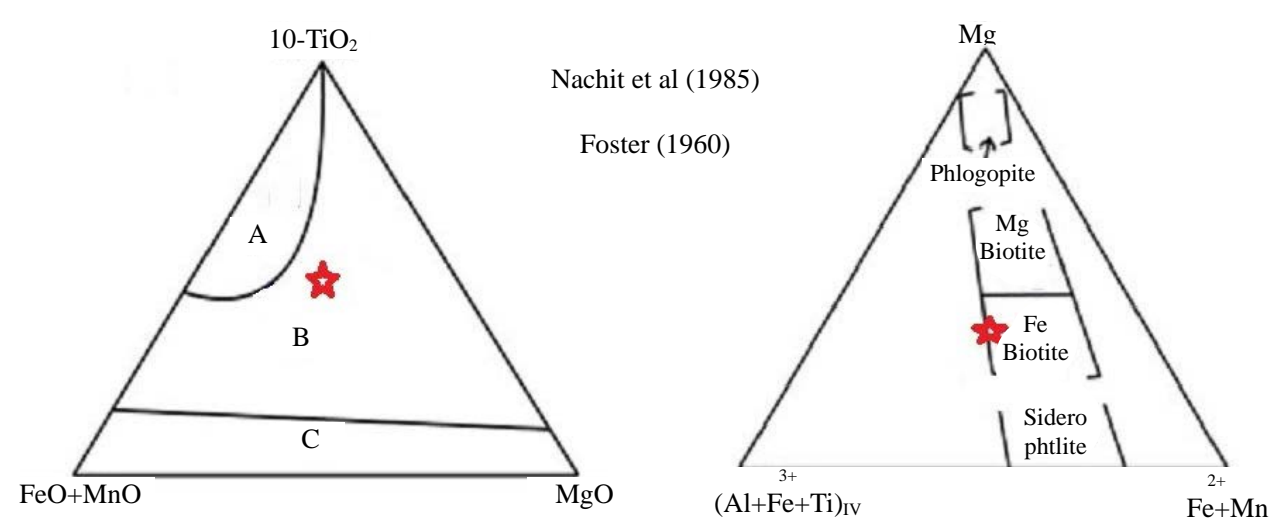

Figure 15. Type and source of biotite plot using EPMA (Nachit, 1985), [17] and (Foster, 1960), [18]. A: primery biotites B: recrystallized biotites C: altered biotites.
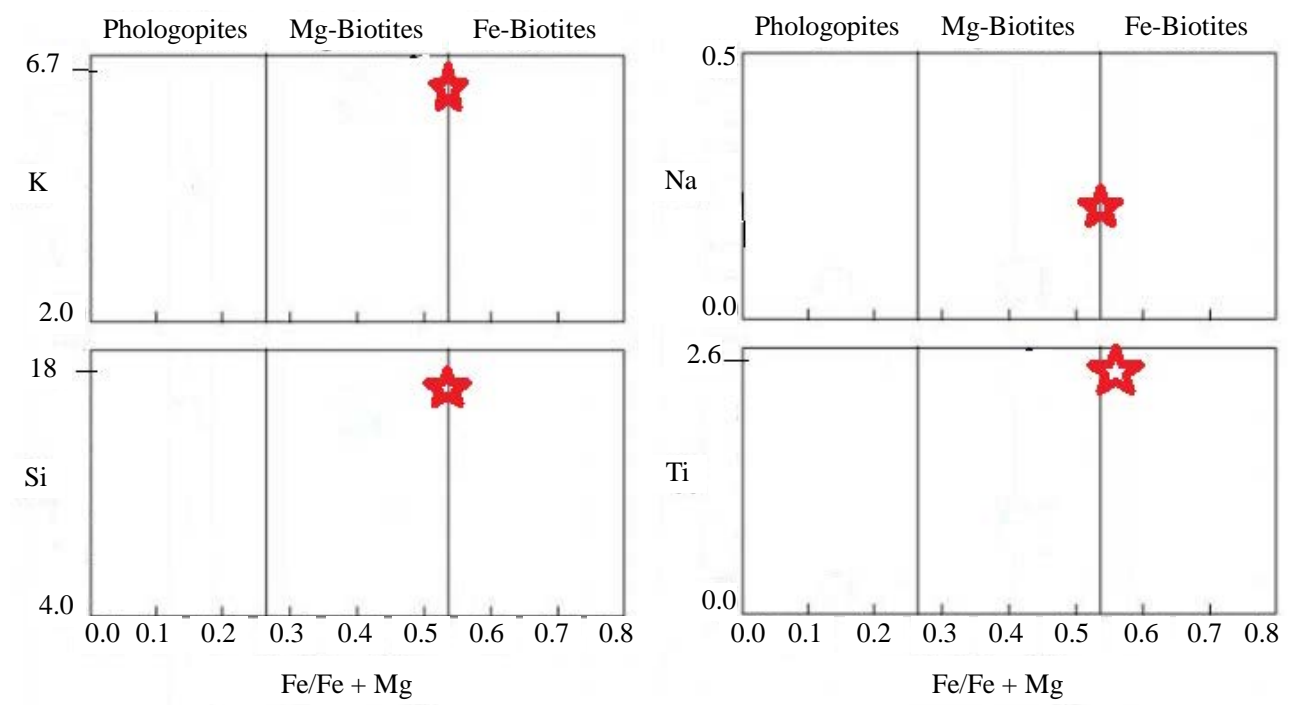

Figure 16. Types of biotites plot using EPMA (Nachit, 1985), [17] and (Foster, 1960) [18].

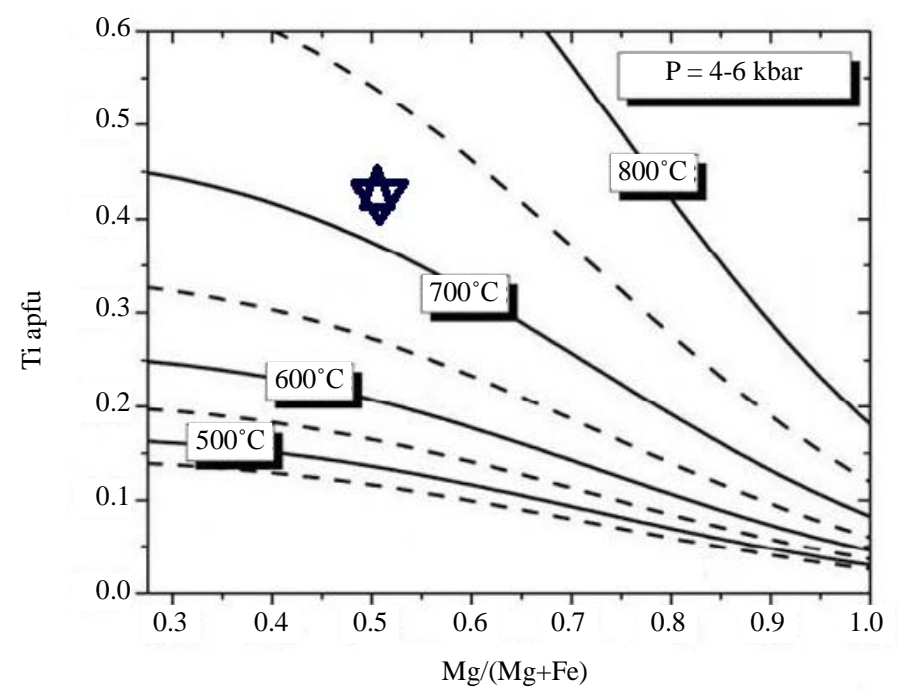

Figure 17. $\mathrm{Mg} /(\mathrm{Mg}+\mathrm{Fe})$ versus Ti apfu plot for thermometry of formation of biotite using EPMA analysis (Henry, 2005) [19]. 


$$
\begin{aligned}
& \mathrm{Ti}=\mathrm{Ti} \text { apfu }=\mathrm{Ln} \mathrm{Ti} \\
& \mathrm{A}=-2.3594 \\
& \mathrm{~B}=4.6482 \mathrm{e}^{-9} \\
& \mathrm{C}=-1.7283
\end{aligned}
$$

Based on this graph the probed biotite sample of Qohrud area shows the formation temperature of 730 degrees centigrade.

Based on other graph the probed samples of the area have formation temperatures varying from 650 to 900 degrees centigrade, this plagioclase formation temperature corresponds with average combination of andesine and oligoclase.

\subsection{Temperature, Pressure, and Depth Measurement Graphs}

With regard to the Rb-Sr depth measurement graph [20] the approximate formation depth and mass replacement depth pressure of the Qohrud area can be determined; Figure 18. Figure 19 also illustrates the temperature measurement graph for the samples of the area, [28].

Based on this graph, the source for most of the rocks based on the amount of $\mathrm{Rb}$ to $\mathrm{Sr}$ in depths of 20 to 30 kilometers from the earth's surface is located depending of the impact locations.

Based on this graph, the formation temperature of the rock of the Qohrud batholithic mass is mostly 900 to 1000 degrees centigrade. The M582 sample has a temperature of over 1000 degrees centigrade and the M84 and M35 samples are located on the 1000 degrees centigrade curve. Figure 20 illustrates the symbols in use plots.

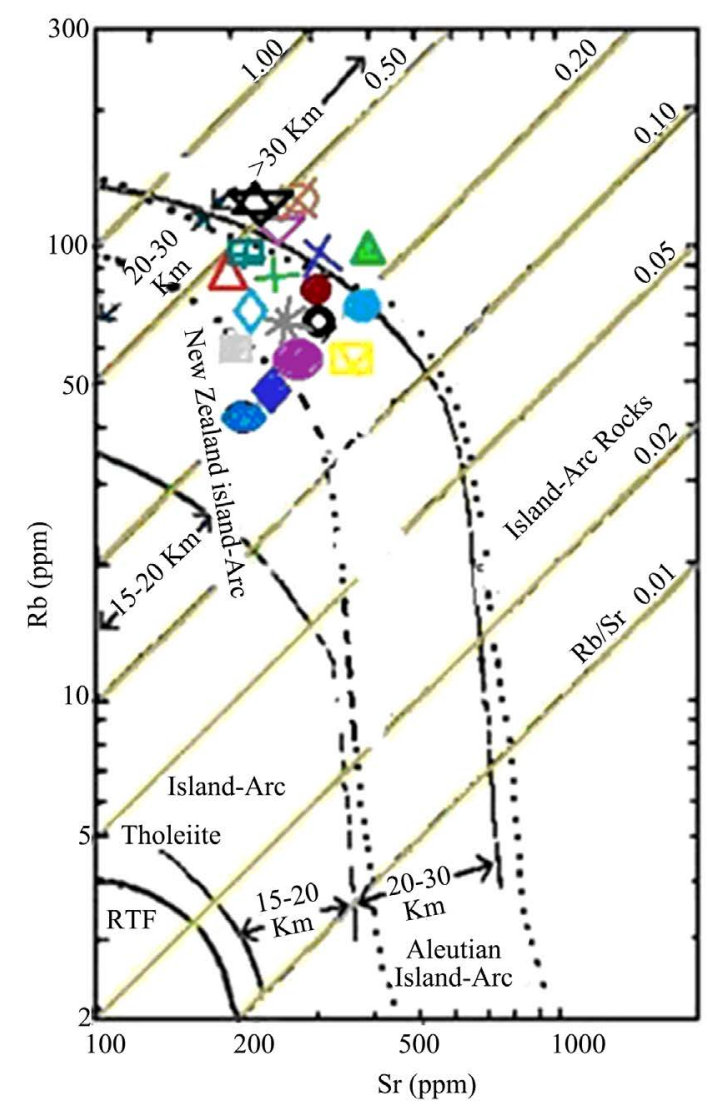

Condi 1976

Figure 18. Sr-Rb plot for depth of origin of magmas (Condi, 1976) [20]. 


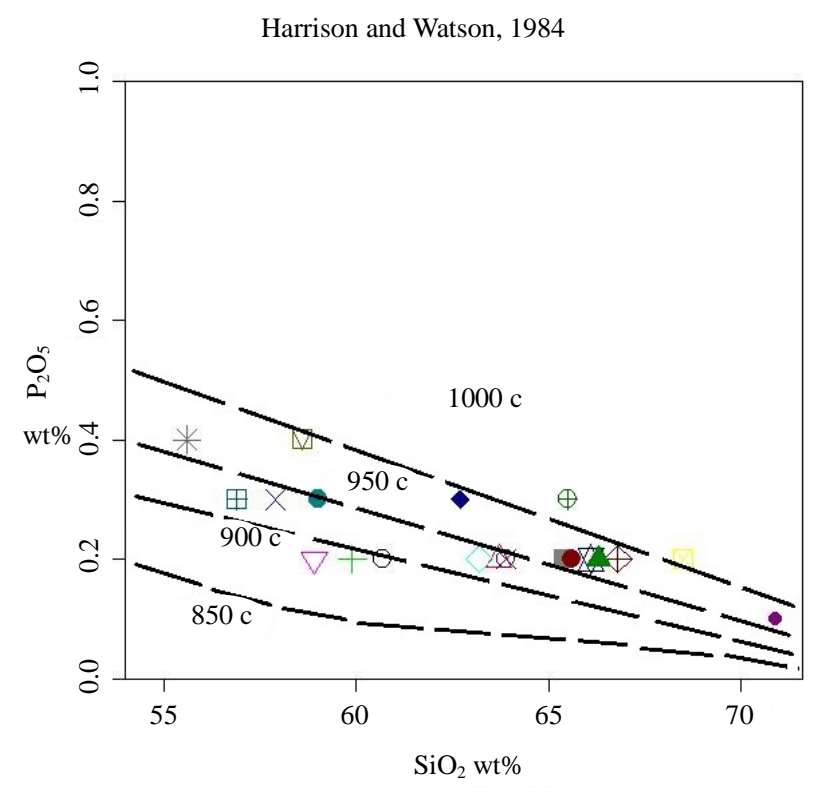

Figure 19. $\mathrm{SiO}_{2}-\mathrm{P}_{2} \mathrm{O}_{5}$ plot for temperature measurement (Harrison and Watson, 1984) [28].

\begin{tabular}{|c|c|c|c|c|c|}
\hline \multirow[t]{2}{*}{ M1 } & \multirow[b]{2}{*}{0} & \multirow[t]{2}{*}{1} & M84 & $\bar{\nabla}$ & 14 \\
\hline & & & M90 & 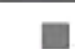 & 15 \\
\hline M12 & $\Delta$ & 2 & M97 & $\Leftrightarrow$ & 16 \\
\hline \multirow[t]{2}{*}{ M13 } & \multirow{2}{*}{+} & \multirow[t]{2}{*}{3} & M99 & 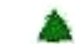 & 17 \\
\hline & & & M103 & A & 18 \\
\hline \multirow[t]{2}{*}{ M16 } & \multirow[t]{2}{*}{$x$} & \multirow[t]{2}{*}{4} & & 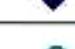 & 19 \\
\hline & & & & ;) & \\
\hline M23 & 0 & 5 & M33 & 8 & 20 \\
\hline M29 & 7 & 6 & & & \\
\hline M35 & & 7 & & & \\
\hline M46 & 光 & 8 & & & \\
\hline M52 & & 9 & & & \\
\hline M57 & & 10 & & & \\
\hline M65 & $\nabla \nabla$ & 11 & & & \\
\hline M71 & $\boxplus$ & 12 & & & \\
\hline M77 & & 13 & & & \\
\hline
\end{tabular}

Figure 20. Symbols of samples number in use for plots.

\subsection{The Relation between Petrography and Petrogenesis}

Using the texture evidences under the microscope, the source of the rocks can be identified. The main mineral- 
ogy of type I granitoids include hornblende, red, brown, or green biotite, titanite (sphene), possibly alanite and magnetite, and sometimes along with ilmenite, and biotite and hornblende usually have apatite inclusions [20], ([21] trans. [22]), therefore, the rocks of the Qohrud area are of I-type. Also, the lack of white mica (muscovite) in the rocks of the area is another indication of type I [23].

Therefore, in terms of mineralogy, the granitoid rocks of the area of study greatly resemble the I-type and can be the result of the melting of volcanic rocks.

\subsection{Economic Geology}

Table 6 shows the average percentage of the minimum grade for extraction (quarry grade) [24].

By comparing these amounts with the data of the area of the study, it can be understood that the amount of elements in the rocks of the area of the study, with the exception of molybdenum is below the economic limit. The amount of molybdenum is higher than the mining grade in the samples of the center of the mass. Therefore, at the center of the pluton (around Qohrud) the amount of molybdenum is $203 \mathrm{ppm}$ in 77 sample that higher than the economic limit.

\section{Conclusions}

With regard to the field and microscopic-mineralogy studies of granitoids of the Qohrud Region of Kashan, and XRD mineralogy and XRF and electron microprobe analysis, the following results can be concluded:

- The closer we get to the center and the south of the pluton (around Qohrud), the rocks become brighter in color and the grains become larger. The closer we get to Qohrud, the altitude becomes higher.

- As the result of the tectonic forces and hydrothermal solutions, taffoni and onion layer corrosion patterns are evident in the rocks of the area.

- Types of alteration include kaolinization, chloritization, oxidation, opacitization, sericitization, and epidotization.

- The samples taken from the Qohrud batholith are of quartz monzonite, granite, granodiorite, and quartz diorite.

- Based on the microscopic observations and modal analysis, both the stones of the Qohrud batholith themselves and its enclaves are more in quartz monzonite ranges, with regard to their locations in the Streckeisen graph.

- With regard to the minerals resulted from the XRD analysis, approximately match with results from the microscopic and modal observations is observed. The compassion between these two methods reveals that minerals such as uraninite and torianite which were not observed under the microscope were clearly distinguished using the XRD method.

- The enclaves present in the granitoids are mostly of quartz monzonite and are typically categorized among both microgranular mafic and otolith type. Also, they are usually from smaller grains and are darker than their host rock.

- Based on the geochemical graph, samples are mostly positioned in adamite (quartz monzonite) section.

- At the center of the pluton, evidence of magma integration and existence of main magma reservoir is observed.

- Granitoid rocks of the area of study greatly resemble the I-type and can be the result of the melting of volcanic rocks.

- The zoning of the plagioclases is both the normal type and variation invert type and has andesine general composition. This is therefore a sign of magma interactions and [means] that the magma has been cooled rapidly.

Table 6. Mining cut of grade of minerals (Shahabpoor, 1384) [25].

\begin{tabular}{|c|c|c|c|c|c|c|c|c|c|c|c|}
\hline Elements & $\mathrm{TiO}_{2}$ & Mn & $\mathrm{Cr}_{2} \mathrm{O}_{3}$ & $\mathbf{N i}$ & Co & $\mathbf{W}$ & Mo & $\mathbf{V}_{2} \mathbf{O}_{5}$ & $\mathrm{Cu}$ & $\mathbf{P b}+\mathbf{Z n}$ & Sn \\
\hline \%grade & 10 & 10 & 10 & 0.26 & 0.06 & 0.2 & 0.003 & 0.3 & 0.2 & 5 & 0.2 \\
\hline Elements & Hg & Sb & $\mathbf{A l}_{2} \mathbf{O}_{3}$ & BeO & $\mathbf{L i}_{2} \mathbf{O}$ & MgO & Ag & $\mathbf{U}_{3} \mathbf{O}_{8}$ & $\mathrm{Ta}_{2} \mathbf{O}_{6}$ & $\mathrm{Na}_{2} \mathrm{O}_{6}$ & \\
\hline \%grade & 0.2 & 1.5 & 45 & 0.2 & 0.015 & 43 & 0.01 & 0.01 & 0.2 & 0.1 & \\
\hline
\end{tabular}


- The probed biotite sample is of iron biotite which belongs to a granite rock sample from the center of the pluton.

- The probed biotite sample of the Qohrud area showed formation temperature of 730 degrees centigrade.

- According to the $\mathrm{Rb}$ and $\mathrm{Sr}$ contents, the source of the rocks is at depths of 20 to 30 kilometers from the earth's surface that are depending on the subduction zone.

- The formation temperature of the stones of the Qohrud batholith is mostly between 900 to 1000 degrees centigrade.

- At the center of the mass (around Qohrud), the amount of molybdenum is higher than the economic limit.

\section{References}

[1] Zahedi, M., Radfar, J., Alaei Mahabadi, S., Hashem Emami, M., Hadadian, M., Afsharianzadeh, E.M. and Farshchi, Z. (1992) Iranian Geology Organization, Kashan 1:100000 Geological Map, No. 6257.

[2] Streckeisen, A.L. (1973) Plutonic Rocks: Classification and Nomenclature Recommended by the I.U.G.S. Sub-Commission on the Systematic of Igneous. Rocks, Geo, Times, 18, 26-30.

[3] Allahyaru, K., Vosoughi, M. and Moayad, M. (2002) Bi-Generational Biotites and Zircons, a Witness for the Source of the Misho Granitoid Anatectic Mass. Collection of Article of the Sixth Seminar of the Iranian Geological Society, Shahid Bahonar University of Kerman.

[4] Rutherford, M.J. and Devin, J. (1988) The May 18, (1980) Eruption of Mount St. Helen, 3. Stability and Chemistry of Amphibole in the Magma Chamber. Journal of Geological Research, 93, 11949-11956. http://dx.doi.org/10.1029/JB093iB10p11949

[5] Vernon, R.H. (2007) Problems in Identifying Restite in S-Type Granites of Southeastern Australia, with Speculations on Sources of Magma and Enclaves. Canadian Mineralogist, 45, 147-178. http://dx.doi.org/10.2113/gscanmin.45.1.147

[6] Didier, J. (1987) Contribution of Enclaves Studies to the Understanding of Origin and Evolution of Granitic Magmas. Geologische Rundschau, 76, 41-50. http://dx.doi.org/10.1007/BF01820572

[7] Sheykhzakariaei, J. and Ghafari Fakherm, M. (2008) Variety of Enclaves and Field Evidences, Microscopy of Magma Integration in Batholithic Granitoid Masses of South Qarveh. Islamic Azad University Scientific Gazette, 18.

[8] Torkian, A. (2001) Translation Clark D.B., 1992, Granitoid Rocjs. Noor Elm Hamedan Publications, 242 p.

[9] Clarke, D.B. (1992) Granitoid Rocks. Chapman and Hall, London, 283.

[10] Hibbard, M.J. (1995) Petrography to Petrogenesis. Prentice Hall, New Jersey, 587 p.

[11] Nelson, S.T. and Montana, A. (1992) Sieve-Textured Plagioclase in Volcanic Rocks Produced by Rapid Decompression. American Mineralogist, 77, 1242-1249.

[12] Gill, R. (2010) Igneous Rocks and Processes, Apractical Guide. Wiley \& Sons Publication, Hoboken, 428 p.

[13] Jafari, S. (2000) Review of Petrography, Petrology, and Geochemistry of the Kashan Qohrud Batholithic Mass. MA. Thesis, $200 \mathrm{p}$.

[14] Farokhpei, H., Shamsipour, R. and Nassresfahani, E. (2010) Varendan Qaza'aan Batholithic Mass. The 4th National Geology Seminar of Payam-e-Noor University.

[15] Debon, F. and Le Fort, P. (1983) A Chemical-Mineralogical Classification of Common Plutonic Rocks and Associations. Transactions of the Royal Society of Edinburgh: Earth Sciences, 73, 135-149. http://dx.doi.org/10.1017/S0263593300010117

[16] Vazirim, M. and Ahmadi, E. (2004) Petrography and Petrology of Volcanic Rocks. Tarbiat Moalem University, Tehran, 10-120.

[17] Nachit, H., Razafimahefa, N., Stussi, J.M. and Caron, J.P. (1985) Composition chimique des Biotites et typologie magmatique des granitoids. C.R. Acadomic Sciences Paris, Series 2, 301, 813-818.

[18] Foster, M.D. (1960) Interpretation of the Composition of Trioc Tahedral Micas. US Geological Survey, Professional Paper 354 B, 11-49.

[19] Henry, D.J., Guidittic, C.V. and Thomson, J.A. (2005) The Ti-Saturation Surface for Low-to-Medium Pressure Metapelitic Biotite: Implications for Geothermometry and Ti-Substitution Mechanisms. Journal of American Mineralogist, 90, 316-328. http://dx.doi.org/10.2138/am.2005.1498

[20] Condie, K.C. (1976) Plate Tectonics and Crustal Evolution. Pergamon Press Inc., Oxford, 145-174.

[21] Chappell, B.W. and Stephens, W.E. (1988) Origin of Infracrustal (I-Type) Granite Magmas. Transactions of the Royal Society of Edinburgh: Earth Sciences, 79, 71-86. 
[22] Shelly, D. (1993) Igneous and Metamorphic Rocks under the Microscop. Chapman and Hall, London, 445.

[23] Asiabanha, E. (1995) Microscopic Study of the Volcanic Rocks and Alteration. Imam Khomeini International University, Qazvin, 630 p.

[24] Harris, N.B.W., Pearce J.A. and Tindle, A.G. (1986) Geochemical Characteristics of Collision-Zone Magmatism. In: Coward, M.P. and Reis, A.C., Eds., Collision Tectonics, Geological Society London Special Publications, London, 6781.

[25] Shahbpour, J. (2010) Economic Geology. Publications of Shahid Bahonar University of Kerman, Kerman, 3rd Edition, $543 \mathrm{p}$.

[26] Internet Database of the Isfahan Province Roads (2012)

[27] Iranian Organization for Geology and Quarry Expedition (2012) Department of Geology of Tehran.

[28] Harrison, T.M. and Watson, E.B. (1984) The Behavior of Apatite during Crustal Anatexis: Equilibrium and Kinetic Considerations. Geochimica et Cosmochimica Acta, 48, 1467-1477. http://dx.doi.org/10.1016/0016-7037(84)90403-4

[29] Deer, W.A., Howie, R.A. and Zussman, J. (1992) An Introduction to the Rock Forming Minerals. 2nd Editions, Longman Scientific \& Technical, London, 696. 
Scientific Research Publishing (SCIRP) is one of the largest Open Access journal publishers. It is currently publishing more than 200 open access, online, peer-reviewed journals covering a wide range of academic disciplines. SCIRP serves the worldwide academic communities and contributes to the progress and application of science with its publication.

Other selected journals from SCIRP are listed as below. Submit your manuscript to us via either submit@scirp.org or Online Submission Portal.
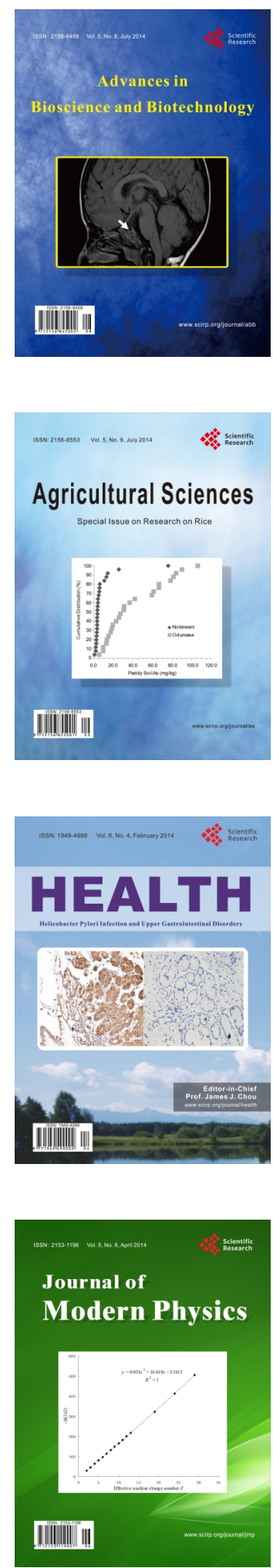
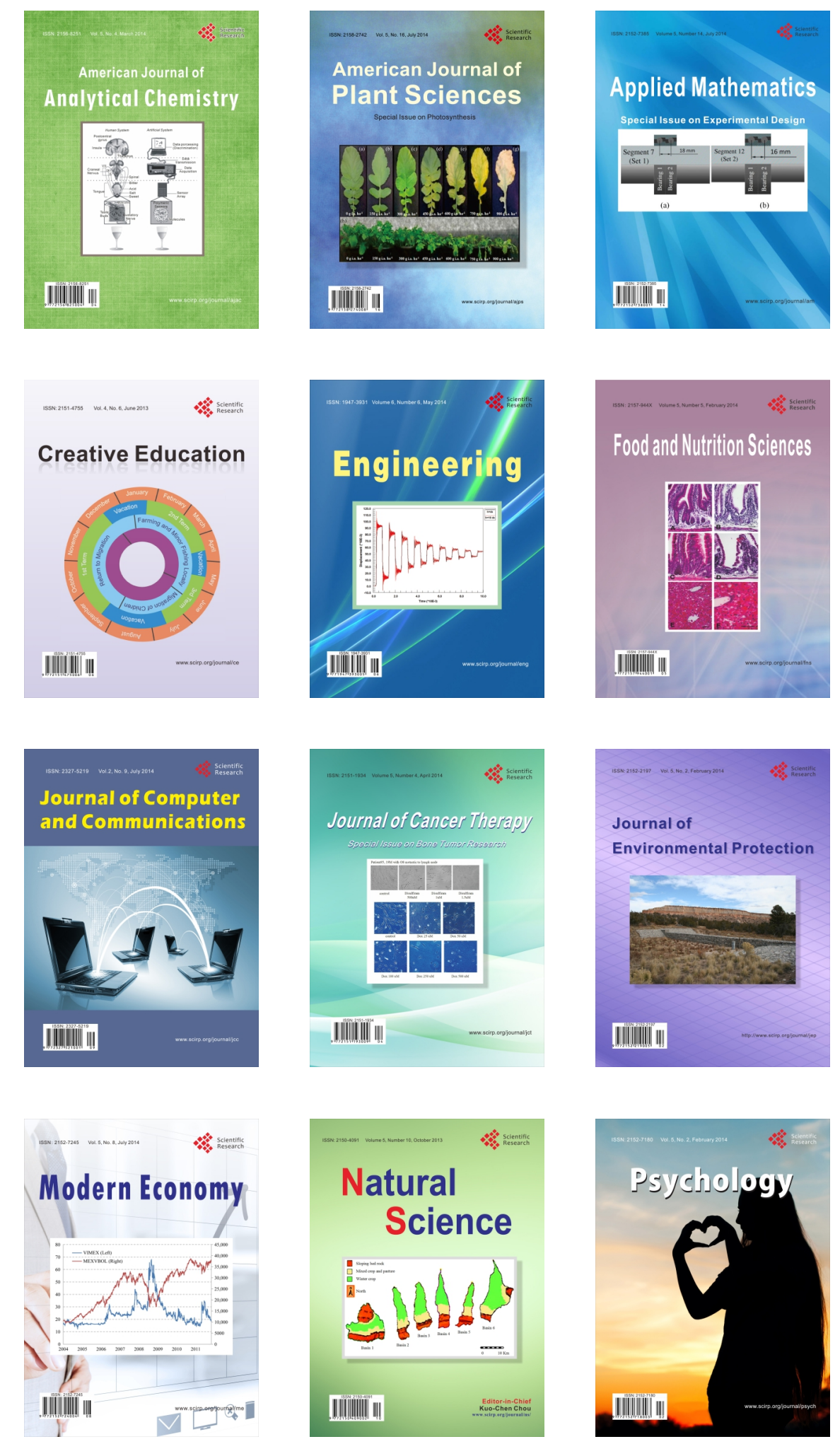